\title{
SYNCHRONOUS PRIMARY OVARIAN ENDOMETRIOID CARCINOMA AND POORLY DIFFERENTIATED ENDOMETRIAL STROMAL SARCOMA
}

Petar Arsenijevic ${ }^{1,2}$ Janko Djuric ${ }^{1,2}$, Slobodan Arsenijevic ${ }^{1,2}$, Milos Z. Milosavljevic ${ }^{3}$ and Slobodanka Mitrovic ${ }^{1,3}$ ${ }^{1}$ Faculty of Medical Science, University of Kragujevac, Kragujevac, Serbia ${ }^{2}$ Department of Gynaecology and Obstetrics, Clinical Center Kragujevac, Kragujevac, Serbia ${ }^{3}$ Department of Pathology, Clinical Center Kragujevac, Kragujevac, Serbia

\author{
SINHRONI PRIMARNI SLABO DIFERENTOVANI SARIKOM STROME \\ ENDOMETRIJUMA I ENDOMETRIOIDNI KARCINOM JAJNIKA

\section{ABSTRACT}

Introduction: The presence of two concomitant genital malignant tumours is a rare phenomenon with an incidence of $0.7 \%$. They are typically localised in the uterus and ovary, and approximately $50 \%$ are identical endometrioid - endometrioid histological type. In the presence of two different histological types of tumours, diagnosis is easier, but because of the small number of reported cases, there are no precise data on their clinical course. Generally, women with synchronous endometrial and ovarian tumours have a better prognosis and are more frequently younger, obese, multiparous and in menopause compared with women who have metastatic ovarian cancer or endometrial cancer.

Case Report: In this work, we present a 53-year-old woman who contacted a gynaecologist because of irregular uterine haemorrhaging. The gynaecological exam revealed a tumour protruding through the cervical canal. The biopsy with initial histopathological diagnosis and additional $E C H O$ and CT evaluations indicated the presence of a cervical tumour spreading over the uterus and both uterine adnexa. After surgical intervention, macroscopic and microscopic analyses of the postoperative material showed the simultaneous presence of two different malignancies, ovarian endometrioid carcinoma and poorly differentiated endometrial stromal sarcoma, which infiltrated all layers of the uterus, cervix and both fallopian tubes.

Conclusion: The prognosis of synchronous tumours of the ovary and the uterus is primarily dependent on the stage and histological type of each tumour. Because of the rather small number of reported cases, a large part of this phenomenon remains unknown. Our report is the first description of the synchronous occurrence of endometrial ovarian carcinoma and uterine stromal sarcoma.

Keywords: Ovarian Neoplasms; Endometrial Neoplasms; Neoplasms, Multiple Primary; Sarcoma; Endometrial Stromal; Carcinoma; Endometrioid.

\section{SAŽETAK}

Cilj rada: Prisustvo dva genitalna maligna tumora u isto vreme je redak fenomen sa zabeleženom učestalošću od 0,7\%. Najčešće su lokalizovani u uterusu i jajniku, od kojih je oko 50\% istovetnog endometrioidno-endometrioidnog histološkog tipa, kada je i diferencijalna dijagnoza prema metastatskom tumoru teška. U slučaju prisustva dva različita histološka tipa tumora, dijagnoza se lakše postavlja, ali zbog malog broja prikazanih slučajema nema preciznijih podataka o njihovom kliničkom toku. Generalno, žene sa sinhronim tumorom ovarijuma i endometrijuma imaju bolju prognozu, češce su mlađe, gojazne, premenopauzalne i nerotkinje, $u$ odnosu na obolele od karcinoma jajnika ili metastatskog karcinoma endometrijuma.

Prikaz slučaja: U ovom radu prezentujemo ženu staru 53 godine kod koje se na ginekološkom pregledu zbog pojave kontaktnog krvavljenja, otkriva tumor koji prolabira kroz endocervikalni kanal. Inicijalna biopsija sa patohistološkom orjentacionom dijagnozom, dodatne CT i EHO pretrage ukazali su na prisustvo tumora uterusa koji zahvata grlić $i$ obe adnekse. Makroskopska i mikroskopska analiza operataivnog materijala pokazuje da se radi o istovremenom prisustvu dva razlicita maligniteta: endometrioidnog karcinoma jajnika i slabo diferentovanog sarkoma strome endometrijuma koji je infiltrisao sve slojeve zida uterusa, grlić i obe tube.

Zaključak: Prognoza sinhronih tumora ovarijuma $i$ uterusa prvenstveno zavisi od stadijuma i histološkog tipa svakog pojedinačnog tumora. Naš prikaz predstavlja prvi opis sinhronog tumora ovarijuma i jajnika u kombinaciji sarkoma strome endometrijuma $i$ endometrioidnog karcinoma jajnika. Zbog malog broja opisanih slučajeva kombinacije različitih histoloških tipova ovaj fenomen je još uvek nedovoljno poznat.

Ključne reči: sinhroni tumori ovarijuma $i$ endometrijuma, sarkom strome endometrijuma, endometrioidni karcinom jajnika.

\section{0}

UDK: 618.14-006.6 ; 618.11-006 / Ser J Exp Clin Res 2012; 13 (4): 139-144 DOI: 10.5937/SJECR13/3193 


\section{INTRODUCTION}

Synchronous malignant tumours of the female genital tract are a rare but known phenomenon, with an incidence of only $0.7 \%{ }^{1}$ Approximately $50 \%$ of synchronous gynaecolog ical malignancies are synchronous tumours of the uterus and ovary (STOUs). ${ }^{2}$ The most common variant of STOUs is the combination of endometrioid carcinomas of the ovary and endometrium, while the occurrence of uterine stromal sarcoma and adenocarcinoma of the ovary has not been yet described in the literature. The diagnosis and treatment of STOUs is no different from the diagnosis and treatment of solitary cancers of the female genital tract. The treatment of choice is surgery, and additional therapeutic procedures, such as chemotherapy and radiotherapy, are used depending on the stage of the disease and histological type of the tumour.

\section{CASE REPORT}

A 53-year-old female patient who was multiparous, in menopause and had a medium body composition reported to the ambulatory gynaecological examination service after irregular uterine haemorrhaging. The haemorrhaging
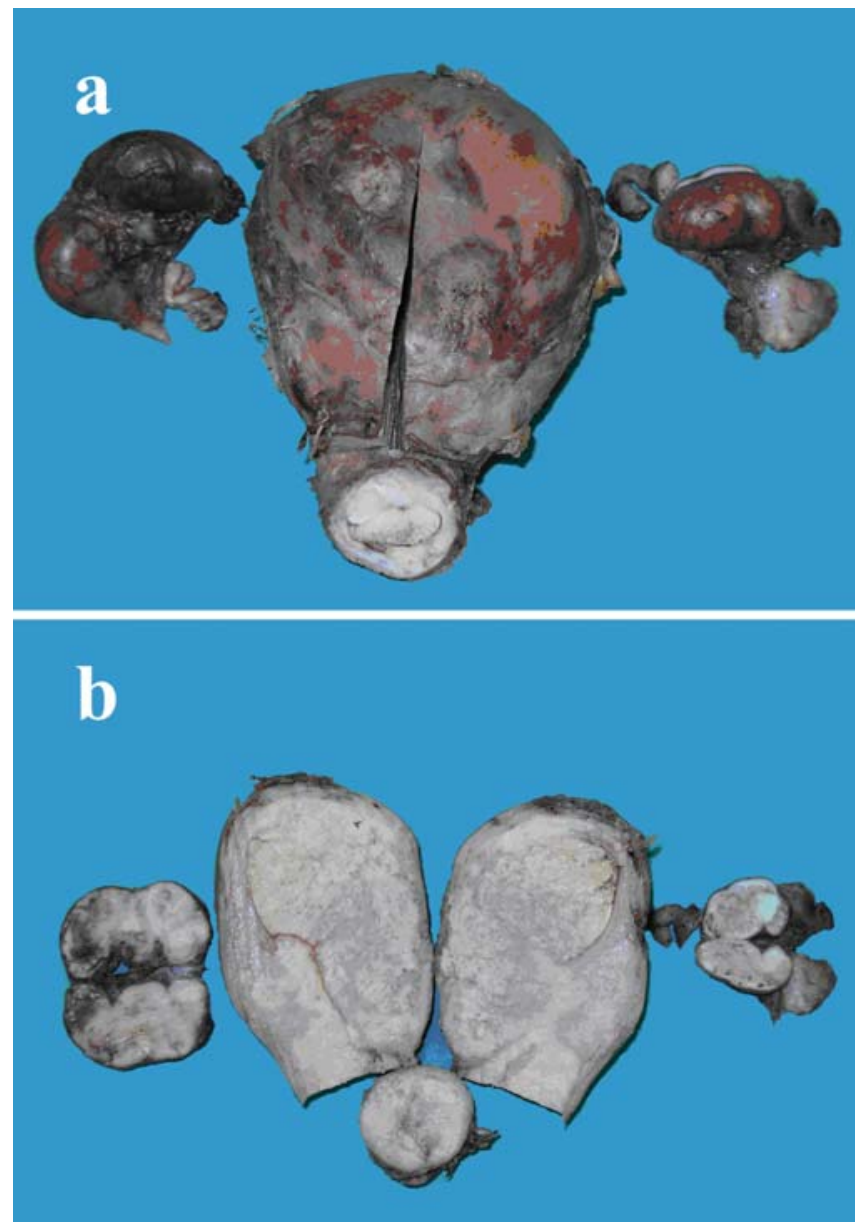

Figure 1: Macroscopic appearance of the resected operative material (a) and the tissue cross section (b). had occurred for the first time since the patient had entered menopause, and she reported no other symptoms. Her medical history indicated that menarche had started at 14 years, and her last regular menstrual cycle was at 51 years of age. The patient did not use oral contraceptive pills or hormone replacement therapy. A bimanual gynaecologic examination was conducted and showed an enlarged uterus. The cervical examination identified a whitish lesion protruding from the endocervical canal. A cervical biopsy was performed, and a spotted lesion of approximately $6 \mathrm{~mm}$ was excised. Haematoxylin-eosin (HE) staining indicated the existence of a tumour with a high-grade malignancy. The differential diagnosis included poorly differentiated adenocarcinoma, stromal sarcoma and mixed Mullerian tumour. It was suggested that a definitive histological diagnosis with the simultaneous staging of the disease could be made after analysing the postoperative materials. Before the operation, the patient underwent ultrasonography (ECHO) and computed tomography. Transabdominal ECHO showed an enlarged uterus, $210 \times 130 \mathrm{~mm}$ in diameter, with a wall thickness of up to $70 \mathrm{~mm}$ and a right adnexal solid mass, $125 \times 58 \mathrm{~mm}$ in diameter. In addition to visualizing the enlarged uterus and right adnexal mass, computed tomography (CT) of the abdomen and pelvis indicated the existence of focal intra-
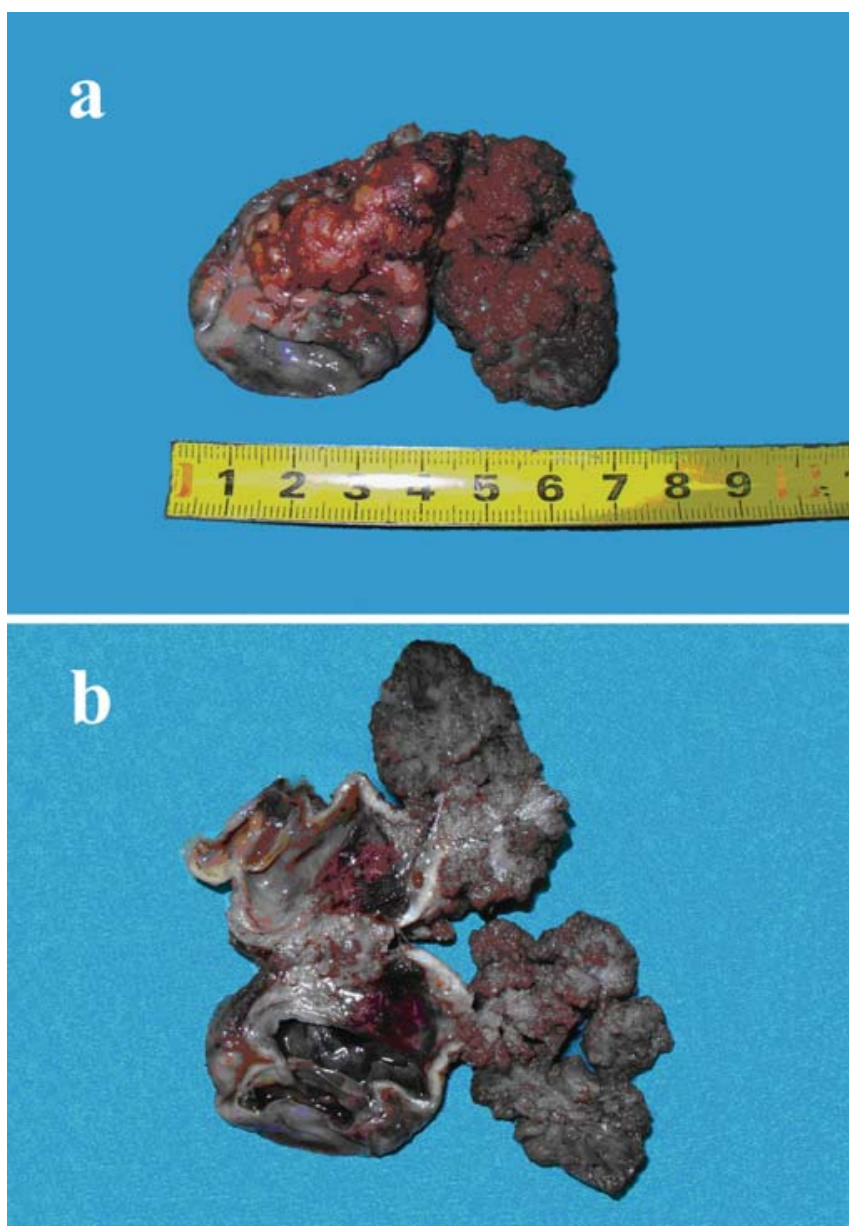

Figure 2: Macroscopic appearance of the right tumour-containing ovary (a) with a solid and partly cystic appearance at the cross section (b). 

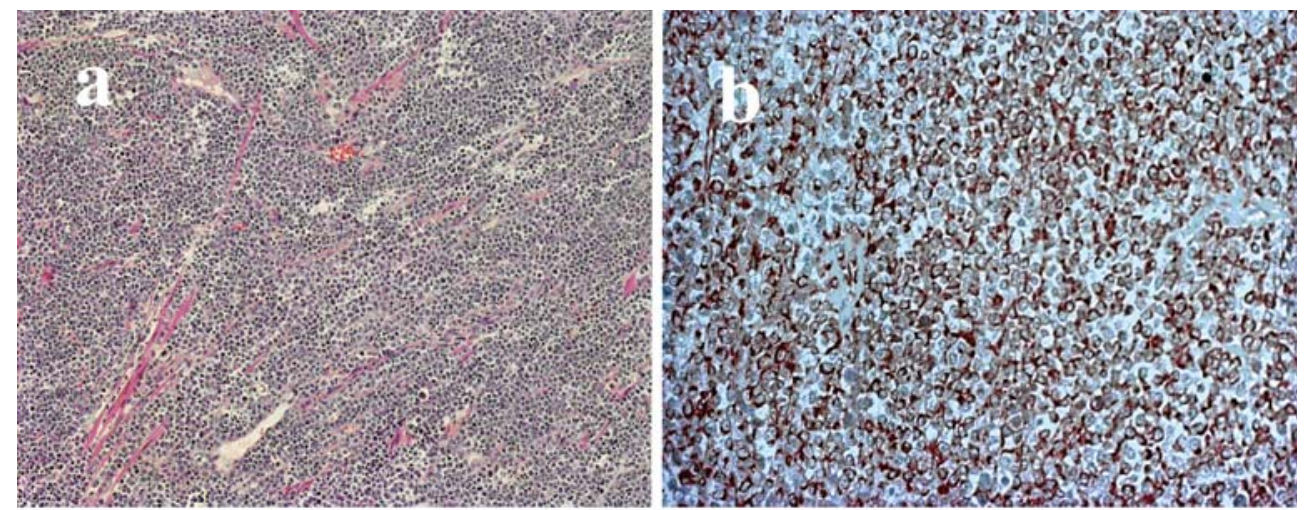

Figure 3: Histological features of a high-grade endometrial stromal sarcoma. a) The tumour contained small and moderately sized cells, with scant cytoplasm and blurred cell boundaries (HE staining technique, x200). Immunohistochemically, the tumour cells were diffusely positive for only b) vimentin, (x400) and remained negative for c) CKAE1/AE3 (x200) and d) CD10 (x400).
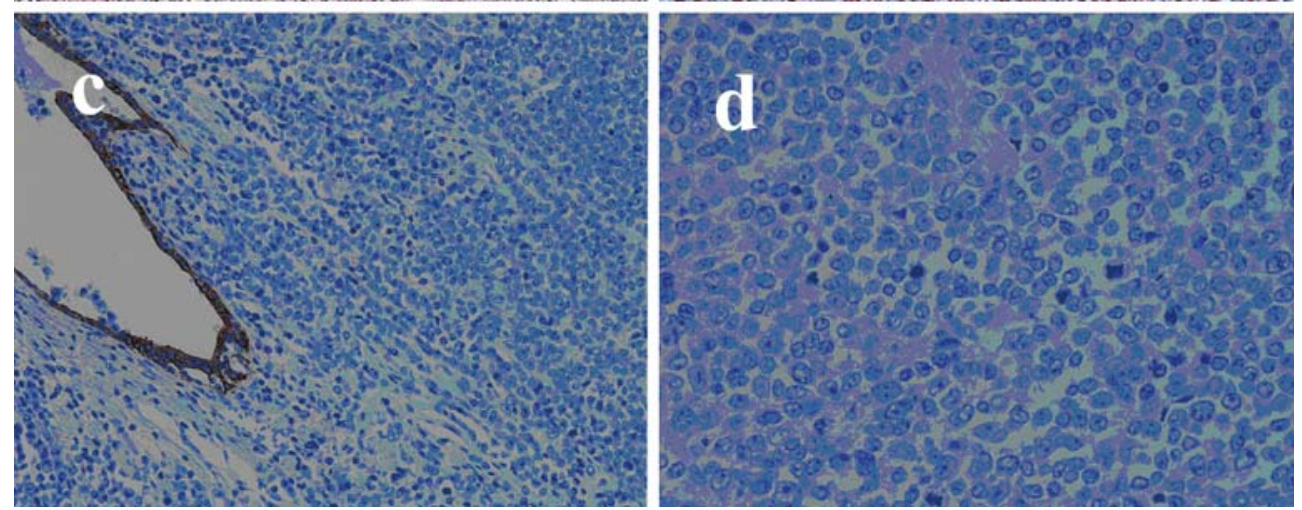

peritoneal metastases. CT of the thorax and a bone scan did not register pathomorphological changes. The gynaecological council decision was to carry out radical surgical treatment due to the possibility of metastases in the right adnexa. The patient underwent exploratory laparotomy, total hysterectomy, lymphanodectomy, total omentectomy, peritoneal biopsy, and peritoneal lavage.

A histopathologic analysis was performed. The uterus, left adnexa and right fallopian tube were initially submitted together, while the right ovarian tumour, samples of the omentum and peritoneum, 30 lymph nodes and $12 \mathrm{ml}$ of ascites fluid were submitted separately. The uterus weight was $700 \mathrm{~g}$, and it was $184 \times 136 \times 84 \mathrm{~mm}$ in diameter, while the cervix was $38 \mathrm{~mm}$ long with a protruding tumour mass (Figure 1a). The tissue cross section demonstrated that the walls of the uterus and cervix were infiltrated by a grey tumour mass, with yellowish areas of necrosis and red areas of haemorrhage. Tumours with similar macroscopic characteristics filled the lumen and infiltrated the walls of both fallopian tubes. The largest diameter of the left ovary was $24 \mathrm{~mm}$, with no visible macroscopic changes (Figure 1b). The right ovarian tumour was enlarged to $72 \times 44 \mathrm{~mm}$ in diameter, with a solid and partly cystic structure at the cross section (Figure 2a, b). The adipose tissue in the omental and peritoneal samples was of regular morphology, and the lymph node structure was homogeneous, with diameters ranging from 7 to $15 \mathrm{~mm}$.

Microscopically, the existence of two morphologically distinct tumours was confirmed. HE staining showed characteristics similar to the tissues of the uterus, cervix and fallopian tubes. The tumour was present in all layers of the uterus wall, with infiltrations into the cervix and fallopian tubes. The tumour contained extensive areas of necrosis and areas of angioinvasion and was composed of small and moderately sized cells, with scant cytoplasms and blurred cell boundaries. The nuclei were vesicular, with prominent nucleoli and numerous mitotic figures (over 30/10 HPF) (Figure 3a). Immunohistochemically, the tumour cells were diffusely positive for only vimentin and remained negative for CD10, S-100, actin, desmin, LCA, EMA, CKAE1/AE3, ER, PR and CA125 (Figure 3b-d). Based on the microscopic analysis and the tumour cell immunophenotype, the diagnosis of a high-grade endometrial stromal sarcoma, FIGO stage IIIa, was made. ${ }^{3}$ A microscopic analysis of the HE-stained samples that matched the cyst found in the right ovary revealed a tumour composed of pseudo-glandular, cribriform and solid areas of atypical, cylindrical and cuboidal cells with eosinophilic cytoplasms (Figure 4a). The nucleoli were hyperchromatic or vesicular, with a moderate number of mitotic figures. The stoma was relatively sparse and contained an inflammatory mononuclear cell infiltrate (Figure 4b). Immunohistochemically, the tumour cells were positive for CK7, CA125, ER and PR and remained negative for vimentin and CEA. The proliferation index was intermediate, with approximately $25 \%$ of the nuclei expressing Ki-67 (Figure 4c-f). Based on the immunophenotype, the diagnosis of a moderately differentiated endometrioid carcinoma of the ovary with no tumour extension (FIGO Ia stage) was made. The left ovary, lymph nodes, and tissue samples of the omentum and peritoneum were all free of tumour deposits. Finally, a cytological analysis of the peritoneal lavage fluid showed no presence of malignant cells. 
Figure 4: Histological features of a moderately differentiated endometrioid carcinoma of the ovary. a) The tumour is composed of pseudo-glandular, cribriform and solid areas of atypical cells (HE staining technique, $\mathrm{x} 200)$. b) The malignant cells are polymorphic, with eosinophilic cytoplasms, hyperchromatic or vesicular nuclei and a moderate number of mitotic figures (HE staining technique, $\mathrm{x} 400$ ). Immunohistochemically, the tumour cells were positive for c) ER (x400) and d) CK7 (x400) and remained negative for e) vimentin (x200). f) The proliferation index was intermediate, and approximately $25 \%$ of the nuclei expressed Ki-67 (x400).
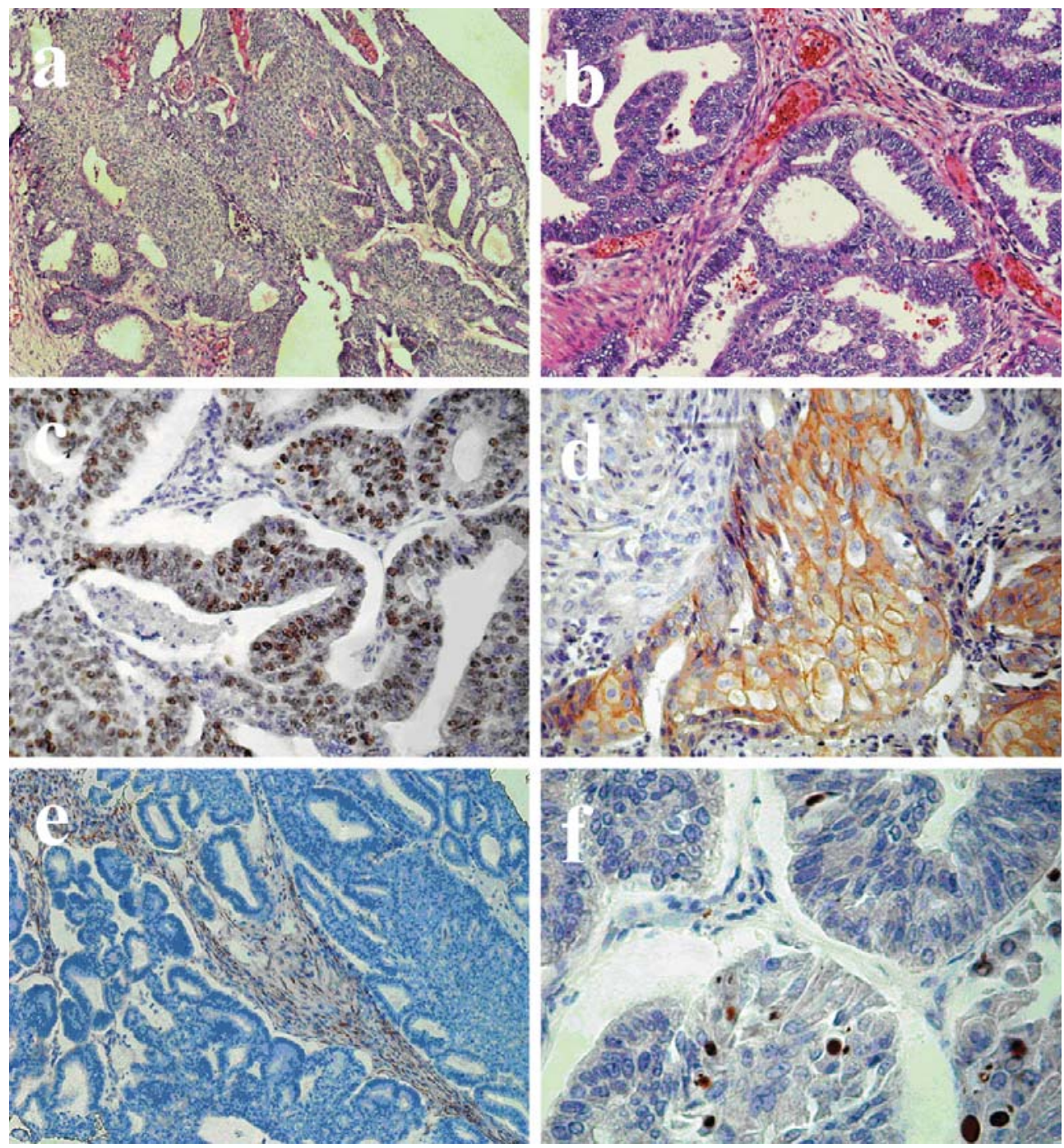

The postoperative course passed without complication, and the patient was released from the hospital on the 10th postoperative day. The oncology council decided to continue the course of treatment with chemotherapy and radiotherapy. However, despite the therapeutic measures implemented, the disease progressed, and secondary deposits were identified in the liver; the patient died 12 months after the diagnosis.

\section{DISCUSSION}

Synchronous malignant tumours of the female genital tract are rare, with an incidence ranging from $0.7 \%$ to $6 \%{ }^{1,4,5}$ They are typically localised in the uterus and ovaries and are rarely found in the cervix and ovaries or cervix and uterus. ${ }^{6,7}$ The phenomenon of more than two simultaneous tumours is extremely rare, although Atasever et al previously described up to 5 simultaneous ovarian cancers in one patient. ${ }^{8}$

Studies have shown that approximately $50 \%$ of synchronous gynaecological malignancies are tumours of the uterus and ovaries. ${ }^{2}$ Their incidence and prevalence is still a subject of debate because of the large differences in the observed results, which are primarily due to different research approaches. ${ }^{9}$ For instance, population studies including women with ovarian cancer have reported an incidence of less than $3 \%$, while analyses of first-stage endometrial carcinoma have reported an incidence of STOUs of $0.31 \% .^{10-12}$ Zaino et al have claimed that the incidence of STOUs in women with ovarian cancer is $10 \%$ and no more than $5 \%$ in women with endometrial cancer, while Irving has reported an incidence of $15-20 \%{ }^{13,14}$ This inconsistency is associated with the different characteristics of the analysed populations, sample size, more organised prevention methods and more precise diagnostics. This is particularly important in the case of cancers with identical endometrioid histological types, with many previously well-defined pathomorphological criteria for the detection of STOUs. ${ }^{15,16}$ The histopathological diagnosis of different histological types of STOUs is not a problem due to the clearly defined microscopic images and different tumour immunophenotypes.

The most common histological type of STOUs is endometrioid carcinoma in both locations. ${ }^{17}$ Serous and clearcell carcinomas are less frequent, and few cases, if any, are 
related to the combination of granulosa cell tumour of the ovary and endometrial carcinoma. ${ }^{18}$ In a series of 30 cases of STOUs, Rodolakis et al described only one case of uterine endometrioid carcinoma and carcinosarcoma of the ovary. ${ }^{19}$ The relatively small number of individual cases of non-endometrioid types of STOUs is the most likely reason for the lack of their precise analysis. ${ }^{6}$ Ours is the first report of STOUs with endometrial stromal sarcoma (SSE) and endometrioid carcinoma of the ovary.

SSE is the second most common mesenchymal tumour of the uterus, with a prevalence of $10 \%$ among all malignancies with a mesenchymal component. ${ }^{20}$ According to the WHO classification, uterine sarcomas are classified into two categories: low-grade SSE and undifferentiated SSE. ${ }^{21}$ Low-grade malignant SSE typically consists of tumour cells similar to stromal cells in the proliferative phase of the menstrual cycle, which infiltrate the myometrium, parametrium and surrounding lymph vessels. In contrast, undifferentiated SSE is characterised by the absence of stromal differentiation and is referred to as poorly differentiated or high-grade undifferentiated. Endometrioid carcinomas are present in approximately 10-30\% of malignant ovarian tumours, bilateral in $28 \%$ of cases and most frequent in the fifth and sixth decades of life. They derive from epithelial metaplasia or the focus of ovarian endometriosis and by definition are made of cells resembling the endometrial epitheluim. ${ }^{21}$ A potential reason for the identification of STOUs comprising SSE and endometrioid carcinoma may be the existence of adenomyosis and ovarian endometriosis. . $2.23^{2}$

Various genetic, embryonic and hormonal factors are possible reasons for the phenomenon of STOUs. ${ }^{24}$ STOUs are thought to be associated with hyperoestrogenism during chronic anovulation, polycystic ovary syndrome, obesity, oestrogen-producing ovarian tumours and hormone therapy. ${ }^{25}$ The multiple genetic alterations observed suggest that the tumours develop independently, ${ }^{14}$ and Lynch syndrome is present in 7-9\% of patients with STOUs. ${ }^{26,27}$ Most likely, STOUs are caused by different and still unknown aetiological factors. ${ }^{28}$ The average age of patients with STOUs is 49-52 years. ${ }^{6,13}$ In contrast to STOUs, ovarian and endometrial cancers occur in older, multiparous, postmenopausal, obese women who often suffer from diabetes or hypertension. ${ }^{2}$ The patient we presented was 52 years old and multiparous with no other features characteristic of patients with STOUs.

The GOG study showed that patients with STOUs have a much better prognosis compared with patients with metastatic ovarian and endometrial cancers. The ten-year survival rate is $80 \%$, and it is mainly related to the most common endometrioid/endometrioid type of STOUs. ${ }^{6,13}$ The better prognosis of STOUs is most likely due to the early detection of ovarian cancer because the illness typically presents as abnormal bleeding from the uterus. ${ }^{19}$ This does not apply to our patient, in whom the disease was discovered in an advanced stage, which is why her overall survival was only thirteen months. The best course of treatment is surgery with adjuvant chemotherapy and radiotherapy. Despite all the available treatment measures, most patients do not live for more than two years after the diagnosis due to the occurrence of metastasis or relapse within the first six months of this pernicious illness. ${ }^{29}$

\section{CONCLUSION}

The prognosis of synchronous tumours of the ovary and the uterus is primarily dependent on the stage and histological type of each tumour. Because of the rather small number of reported cases, a large part of this phenomenon remains unknown. Our report is the first description of the synchronous occurrence of endometrial ovarian carcinoma and uterine stromal sarcoma.

\section{ABBREVIATIONS}

STOUs - synchronous tumours of the ovary and uterus;

HE - haematoxylin-eosin;

ECHO - ultrasonography;

CT - computed tomography;

LCA - leucocyte common antigen;

EMA - epithelial membrane antigen;

CK - cytokeratin;

ER - oestrogen receptor;

PR - progesterone receptor;

CEA - carcinoembryonic antigen;

FIGO - International Federation of Gynecology and Obstetrics; SSE - endometrial stromal sarcoma.

\section{REFERENCES}

1. Tong SY, Lee YS, Park JS, Bae SN, Lee JM, Namkoong SE. Clinical analysis of synchronous primary neoplasms of the female reproductive tract. Eur J Obstet Gynecol Reprod Biol 2008;136:78-82.

2. Gungor T, Kanat Pektas M, Ustunyurt E, Mollamahmutoglu L. Synchronous primary tumors of the female genital tract:a single center experience. Arch Gynecol Obstet, 2009;279:667-72

3. Staging classifications and clinical practice guidelines of gynaecological cancers by the FIGO Committee on Gynecologic Oncology.3. $3^{\text {rd }}$ ed. Oxford: Elsevier, 2000.

4. Eisner RF, Nieberg RK, Berek JS. Synchronous primary neoplasms of the female reproductive tract. Gynecol Oncol 1989;33:335-9.

5. AlHilli MM, Dowdy SC, Weaver AL et al. Incidence and factors associated with synchronous ovarian and endometrial cancer: A population-based case-control study. Gynecologic Oncology 2012;125:109-13.

6. Soliman PT, Slomovitz RR, Broaddus RR et al.Synchronous primary cancers of the endometrium and ovary: a single institution review of 84 cases. Gynecol Oncol, 2004; 94:456-462. 
7. Huang YD, Hung YC, Yeh LS, Chiang IP, Zeng GC, Chang WC. Synchronous ovarian endometrioid adenocarcinoma and endocervical mucinous adenocarcinoma. Taiwan J Obstet Gynecol 2006;45:264-7.

8. Atasever M, Yilmaz B, Dilek G, Akcay EY, Kelekci S. Synchronous primary carcinoma in 5 diferent organs of a female genital tract: an unusual case and review of the literature. Int J Gynecol Cancer 2009;19:802-7.

9. Singh N. Synchronous tumours of the female genital tract. Histopathology 2010;56:277-85.

10. Williams MG, Bandera EV, Demissie K, RodriguezRodriguez L. Synchronous primary ovarian and endometrial cancers: a population-based assessment of survival. Obstet Gynecol 2009;113:783-9.

11. van Niekerk CC, Bulten J, Vooijs GP, Verbeek AL. The association between primary endometrioid carcinoma of the ovary and synchronous malignancy of the endometrium. Obstet Gynecol Int, 2010; doi: $10.1155 / 2010 / 465162$.

12. Pan Z, Wang X, Zhang X, Chen X, Xie X. Retrospective analysis on coexisting ovarian cancer in 976 patients with clinical stage I endometrial carcinoma. J Obstet Gynaecol Res, 2011;37:352-8.

13. Zaino R, Whitney C, Brady M, Degeest K, Burger R, Buller R. Simultaneously detected endometrial and ovarian carcinomas-a prospective clinicopathologic Study of 74 cases: a Gynecologic Oncology Group Study. Gynecol Oncol 2001;83:355-62.

14. Irving JA, Catasus L, Gallardo A et al. Synchronous endometrioid carcinomas of the uterine corpus and ovary: alterations in the b-catenin (CTNNB1) pathway are associated with independent primary tumors and favorable prognosis. Hum Pathol, 2005;36:605-19.

15. Ulbright TM, Roth LM. Metastatic and independent cancers of the endometrium and ovary: a clinicopathological study of 34 cases. Hum Pathol, 1985;16:28-34.

16. Scully RE, Young RH, Clement PB. Tumors of the ovary, maldeveloped gonads, fallopian tube, and broad ligament. Atlas of tumor pathology. Armed Forces Institute of Pathology, Bethesda, 1998.

17. Yang YH, Chen RJ, Lin MC, Cheng SP, Ting-Chen Chang TC. Synchronous primary ovarian and endometrial cancer with a fair prognosis in a young woman. Taiwan J Obstet Gynecol 2010;49:97-100.
18. Lin YC, Chu TY, Ding DC. Synchronous primary ovarian granulosa cell tumor and endometrial cancer. Taiwan J Obstet Gynecol 2011;50:546-8.

19. Rodolakis A, Thomakos N, Akrivos N et al. Clinicopathologic insight of simultaneously detected primary endometrial and ovarian carcinomas. Arch Gynecol Obstet 2012;285:817-21.

20. Abeler VM, Royne O, Thoresen S, Danielsen HE, Nesland JM, Kristensen GB. Uterine sarcomas in Norway. A histopathological and prognostic survey of a total population from 1970 to 2000 including 419 patients. Histopathology 2009;54:355-64.

21. Hendrickson MR, Tavassoli FA, Kempson RL et al. Mesenchymal tumours and related lesions. In Tavassoli FA \& Deville P(eds.). Pathology and genetics of tumours of the breast and female organs. Lyon: IARC Press,2003,233-44.

22. Kondi-Paphitis A, Smyrniotis B, Liapis A, Kontoyanni A, Deligeorgi H. Stromal sarcoma arising on endometriosis. A clinicopathological and immunohistochemical study of 4 cases. Eur J Gynaecol Oncol 1998;19:588-90.

23. Yantiss RK, Clement PB, Young RH. Neoplastic and preneoplastic changes in gastrointestinal endometriosis: a study of 17 cases. Am J Surg Pathol 2000;24:513-24.

24. Hiroaki F, Toshiharu M, Manabu Y et al. Genetics of synchronous uterine and ovarian endometrioid carcinoma: combined analyses of loss of heterozygosity, PTEN mutation, and microsatellite instability. Hum Pathol 2002;33:421-8.

25. Uccella CS, Melton JL, Bergstralh EJ et al. Risk Factors for Developing Multiple Malignancies in Patients with Endometrial Cancer. Int J Gynecol Cancer 2011;21:869-901.

26. Kim MK, Sang Yong Song SY, Do IG et al. Synchronous gynecologic malignancy and preliminary results of Lynch syndrome. J Gynecol Oncol 2011;22:233-8.

27. Walsh CS, Blum A, Walts A et al. Lynch syndrome among gynecologic oncology patients meeting Bethesda guidelines for screening. Gynecol Oncol 2010;116:516-21.

28. Herrinton LJ, Voigt LF, Weiss NS, Beresford SAA, Wingo PA. Risk factors for synchronous primary endometrial and ovarian cancers. Annals of Epidemiology 2001;11:529-33.

29. Xue WC, Cheung AN. Endometrial stromal sarcoma of uterus. Best Practice \& Research Clinical Obstetrics and Gynaecology 2011;25:719-32. 